\title{
IMAGENS DO INSÓLITO E DO MARAVILHOSO: CONSTRUÇÕES DA HISTORICIDADE NA LITERATURA HISPANO-AMERICANA
}

\author{
Ana Lúcia Trevisan ${ }^{1}$
}

\begin{abstract}
Resumo: O trabalho estuda os sentidos históricos da narrativa fantástica e do realismo maravilhoso na obra Aura, de Carlos Fuentes, Pedro Páramo, de Juan Rulfo e Cien años de soledad, de Gabriel García Márquez a fim de discutir as ambivalências do fantástico, presentes nas letras hispânicas. Dessa forma, procura perceber as nuances significativas dos elementos insólitos que corroboram para a discussão das identidades plurais e para a construção da historicidade na América Hispânica.

Palavras-Chave: Fantástico, Realismo maravilhoso, Historia, América Latina, Identidade.
\end{abstract}

Resumen: el trabajo estudia los sentidos históricos de la narrativa fantástica y del realismo maravilloso en la obra Aura, de Carlos Fuentes, Pedro Páramo, de Juan Rulfo yCien años de soledad, de Gabriel García Márqueza fin de dis- cutir las particularidades del género presente en las letras hispánicas. Con eso, busca percibir los aspectos significativos de los elementos insólitos que corroboran para la discusión de las identidades múltiples y para la construcción de la historicidad en América Hispánica.

Palabras clave: Fantástico, Realismo maravilloso, Historia, América Latina, Identidade.

As formas de representar o real no âmbito da arte literária não estão obrigadas a recorrer tão somente às formulações estéticas de tipo realista, afinal, o real que se expressa na ficção é sempre, em si mesmo, uma quimera muito bem construída, mas, ainda assim, uma quimera que se faz pura essência significativa de realidade. Em tantos momentos a literatura, deliberadamente, se explicita como impossibilidade e escolhe imagens e situações que não encontram resposta no mundo que todos concebemos como real. No entanto, é possível afirmar que nesse momento, ela deixa de representar ou significar? Os textos literários tendem a impactar os leitores

${ }^{1}$ Docente do Programa de Pós-Graduação em Letras, da Universidade Presbiteriana Mackenzie de São Paulo; doutora em Literaturas Espanhola e Hispano-Americana pela Universidade de São Paulo (USP); integrante do GT "Vertentes do insólito ficcional”, da Associação Nacional de Pesquisa e Pós-Graduação em Letras e Linguística (ANPOLL). Endereço eletrônico: ana.trevisan@mackenzie.br. 
por diferentes motivos, mas, muito do fascínio imanente à leitura literária, reside em sua forma precisa e ao mesmo tempo difusa de tecer entrelinhas textuais, que não explicitam tão-somente sentidos unívocos. Na combinação das palavras que revelam e escondem seus significados, a literatura instiga seus leitores e permite diálogos históricos surpreendentes.

Quando pensamos o longo percurso da história literária identificamos os relatos míticos, os contos de populares, os contos de fada como manifestações importantes que fazem parte de uma memória imaginativa universal. O imaginário de diferentes povos está permeado por tais formulações narrativas que legitimam, pelo viés do fantástico e do maravilhoso, os sentidos da cultura e da identidade de diferentes povos. Inegável a ideia de que nos constituímos como sujeitos também pela nossa capacidade de imaginar, de interagir com formas de representação do real, que não pertencem necessariamente a nossa experiência empírica.

$\mathrm{Na}$ história da literatura universal, sob o gênero fantástico, surgem diferentes tipos de relatos que se definem por gravitar, em suas temáticas, na esfera do impossível, do absurdo ou do sobrenatural. O gênero, reconhecidamente movediço, possui uma dimensão ambivalente, percebida na proliferação de nomes que tentam definir seu status e nas formulações narrativas a ele vinculadas. Os limites entre os termos "realismo fantásti- co", "realismo mágico" ou "maravilhoso", o "neo-fantástico" são sutis, as- sim como as fronteiras com os reconhecidos gêneros vizinhos o "fantasy" e a "ficção cientifica". A pluralidade de obras e de reflexões teóricas sobre o universo do fantástico não devem apontar para o hermetismo, ao contrario, nada mais impactante e inteligível do que esse gênero capaz de descrever a realidade dos fatos e dos sentimentos humanos por meio de imagens não empíricas, por meio do encantamento perene provocado pelos sentidos simbólicos e metafóricos.

O clássico mundo maravilhoso, explicitado na forma do "era uma vez" dos contos de fada, se redimensionou em novas construções narrati- vas que provocaram os leitores a experimentar possibilidades de compre- ensão do real, marcadas pelo universo imaginativo do medo, da dúvida e das ambiguidades. A literatura foi invadida por fantasmas, mortos vivos, vampiros e lobisomens, criaturas fantásticas que significaram a força motriz da literatura fantástica do século XIX, com suas nuances de incerteza e dubiedade. No século $X X$, estas figuras monstruosas também se reconfiguram e o monstro deixa de ser exterior ao homem, não está mais escondido ou envolto em brumas ou mansões mal assombradas. O monstruoso agora 
habita a interioridade dos sujeitos, se traduz em marcas no seu corpo e o homem surge, a partir de alguns relatos fantásticos do século $X X$,como a própria imanência do fantástico. $O$ homem e suas angústias existenciais, seu mundo moderno caótico, suas guerras, suas ditaduras e sua rotina me- cânica e burocrática tornaram-se em si mesmo a imagem do absurdo, do insólito. Depois da obra A metamorfose, de Franz Kafka, a literatura fantás- tica não pode mais ser vista ou lida da mesma maneira, pode-se dizer que naquela manhã GregorSamsa despertou e viu que havia se transformado em um inseto gigante e a literatura fantástica também. Esse "inseto gigan- te" também possui uma história nas letras hispânicas onde percebemos a constância e a permanência do gênero na obra dos escritores latinoamericanos como Julio Cortazar, Juan Rulfo, Jorge Luis Borges, Carlos Fuentes, Bioy Casares, Gabriel Garcia Márquez, entre outros.

No âmbito das Letras hispânicas, sempre que se pensa a perspectiva da elaboração estética, da busca de uma forma singular de construção da narrativa, cabe destacar a importância do momento do boom do romance latino-americano, fundamental dentro da história literária da América Latina. O boom foi estudado e discutido por inúmeros críticos e também pelos escritores representantes desse momento, questões relacionadas ao seu contexto literário, por exemplo, foram estudadas na obra Narradores de esta América (1969), do crítico uruguaio Emir Rodríguez Monegal, que en- tende as origens da explosão da produção literária latino-americana a partir do surgimento de uma nova forma de narrar, de uma nova linguagem. Al- guns autores do boom, destacaram-se por obras alinhadas na perspectiva do fantático e do realismo maravilhoso, como Pedro Páramo, de Juan Rulfo, Cien años de soledad, de Gabriel Garcia Márquez, Aura, de Carlos Fuentes. A renovação do gênero se redimensionou nesses escritores em estéticas renovadorascapazes de imprimir uma nova possibilidade de leitura das realidades latino-americanas. A revolução que se operou na elaboração formal da ficção hispano-americana foi responsável pelo surgimento de uma nova concepção da arte de narrar o fantástico. A linguagem tornou-se uma realidade paralela à realidade mesma que estava sendo retratada. Estas renovações formais foram o principal traço e o grande trunfo do bo- om das literaturas americanas da década de 60, que conseguiram projetar as letras do continente para as latitudes mais diversas. Emir Rodríguez Mo- negal em seu livro El boom de la novela latinoamericana, assinala houve "el boom como fenómeno publicitario, de raíz industrial, y el boom como fe- 
nómeno literario que precede y acompaña al anterior" (MONEGAL, 1972, p. 11).

A forma de apresentar as nuances temáticas impõe a cada leitor uma provocação - sempre determinante na leitura - permitindo que a análise e interpretação dos textos atuem no imaginário dos leitores, removendo, por vezes, a impermeabilidade de certos pontos de vista. Sempre que o leitor necessita realizar o esforço para montar ou desmontar um texto lite- rário surge um questionamento mais amplo: percebemos que o nosso coti- diano, repleto de discursos imanentes, também nos exige um esforço con- tinuo de desvendamento? Não estamos o tempo todo interagindo e reorganizando as narrativas que lemos no dia a dia? Os experimentalismos literários nos ajudam a perceber que tudo o que se propõe como constru- ção discursiva, invariavelmente, configura-se como uma forma de articula- ção possível que exigiu uma montagem, cuja intenção nem sempre é expli- citada em um primeiro momento. Neste sentido, um dos sentidos do boom que se insinua é considerar a formulação da arquitetura textual como um modo de operacionalizar uma percepção crítica a respeito das multifacetas construções discursivas do nosso tempo.

A prosa de García Márquez, que incorpora tanto a tradição ficcional europeia como as tradições da oralidade e das lendas do interior da Colômbia, nos instiga a desvendar um cosmos narrativo em que temas do realismo maravilhoso se desdobram. Em seu primeiro romance, La hojarasca, de 1955, a cidade imaginária de Macondo surge pela primeira vez congregando uma trama cujo foco narrativo está pulverizado nas memórias e opiniões de três personagens durante um funeral. Esse romance, ainda sem tocar os contrastes mais definidores do estilo do autor, torna-se seminal, uma vez que aponta para um aspecto recorrente: a relevância do microcosmos es- pacial como uma dimensão simbólica. Essa primeira Macondo anuncia as outras macondos que surgirão na obra de García Márquez. Desdobradas e metafóricas, elas ressurgem como espaços capazes de evocar a História e de articular a façanha da multiplicação de significantes e significados latinoamericanos.

Partindo dessa primeira Macondo, inevitavelmente chegamos ao romance Cem anos de solidão (1967) e, antes de qualquer reflexão, vale a ressalva de que esse texto parece renovar-se ao longo dos anos com uma vitalidade que despertaria a dúvida quanto à existência de uma fonte da juventude escondida e não mencionada na casa de Úrsula Buendia. A força narrativa de García Márquez se esconde e se revela em um binômio indis- 
sociável, próprio da verdadeira literatura quando esta agrega uma boa história a uma forma diferenciada de narrar. Quando um escritor nos oferece uma 'forma', que revela em si mesma o próprio conteúdo que abarca, estamos diante de um corpo com sua alma.

Cem anos de solidão alcança esse binômio com a perfeição expressa no tempo predestinado à saga familiar dos Buendia e à leitura dos misteriosos pergaminhos intraduzíveis. As peripécias dessa família se desenrolam diante dos leitores ao mesmo tempo em que são apresentados certos pergaminhos indecifráveis, trazidos pelo cigano Melquiades. Esses manuscritos passam de mãos em mãos ao longo do romance, são textos em busca de quem queira e possa decifrá-los. Entretanto, somente nas últimas páginas do romance o sentido desses escritos será revelado. No tempo da leitura dos pergaminhos, realizada pelo último representante da família Buendia, descobrimo-nos submersos em uma aura de fatalidade, pois entendemos que uma verdade final se anuncia e se impõe. Lemos o fim do romance ao mesmo tempo em que conhecemos o fim de Macondo, lemos com os olhos duplicados na figura do narratário. Uma vez que somos leitores do texto que Aureliano Babilônia está decifrando, percebemos que o tempo da nos- sa leitura poderia também inscrever-se no tempo mítico e circular que ordenou a vida em Macondo.

Será permitido habitar Macondo pelo tempo determinado na velocidade da nossa própria leitura e, assim, conviver com Aurelianos e JosésArcadios, sofrer com os amores e os ciúmes de Rebeca ou Amaranta, deleitarnos com a praticidade estarrecedora da matriarca Úrsula Buendia e da objetividade visionária do alquimista e patriarca José Arcádio Buendia. Com assombro observamos a aparição do gelo, do imã ou da fotografia e, por outro lado, desprovidos de total espanto vemos ascender aos céus, Remédios, a bela - já convencidos pela lógica da causalidade interna do romance que tal corpo ofuscante deveria, verdadeiramente, retornar a sua condição celestial. Paralelos a este e a outros acontecimentos maravilhosos, muitos momentos da história latino-americana estão metaforizados nessa proposta de cosmogonia, realizada em Cem anos de solidão. Nesse sentido, a fundação mítica de Macondo também assume os aspectos de uma fundação histórica, a releitura e a consequente reescritura da História faz parte de um grande diálogo entre diferentes textos que se multiplicam em senti- dos críticos.

Em muitos sentidos é possível inscrever a obra de Gabriel García Márquez na esfera estética do realismo maravilhoso. Segundo as perspecti- 
vas críticas da estudiosa da literatura latino-americana, IrlemarChiampi, autora do livro $O$ realismo maravilhoso (1981), esta forma de narrar, ao contrário da narrativa fantástica própria ao século XIX, não procura nenhum efeito emotivo de calafrio, medo ou terror quando expõe um evento insólito. Partindo de uma ideia de que existe uma contiguidade entre o real e o irreal, o realismo maravilhoso propõe um 'reconhecimento do insólito', pois as mitologias, as crenças religiosas, a magia e as tradições culturais tornamse capazes de redimensionar uma reflexão identitária, conduzindo a um retorno ao 'familiar coletivo'. É possível pensar a obra de García Márquez dentro desta perspectiva, uma vez que a causalidade interna do realismo maravilhoso está relacionada com as profundas raízes autóctones de diferentes povos e o encontro com o elemento maravilhoso, na narrativa de García Márquez, pode significar uma reflexão sobre o próprio referente da cultura americana. Com relação ao uso dos mitos na literatura, vale destacar a obra de E. M. Mielietinsk, A poética do mito. Segundo o autor, o ponto crítico quanto ao uso diferenciado dos mitos, por escritores latinoamericanos, reside na questão da experiência da História. Na obra de escritores europeus, de diferentes épocas, é possível perceber-se a presença de uma frustração com o historicismo, com o "pesadelo da história", o que conduziria a uma fuga para o universo dos mitos. No caso dos escritores latino-americanos, que possuem o elemento mítico tantas vezes inserido na sua historicidade, a utilização dos mitos significa mais um componente na busca de uma reflexão sobre suas particularidades históricas. Mito e história não se opõem na literatura americana, estão conjugados, pois remetem às fundações utópicas da própria ideia de América, da descoberta e conquista dos povos americanos.

As referências históricas aos descobrimentos, às colonizações ou mesmo aos movimentos de independências, que se rearticulam no interior da cidade de Macondo, juntamente com as peripécias da estirpe dos Buendia, têm ocupado estudos literários há 40 anos. No entanto, se pensarmos em uma primeira e sempre irrepetível leitura do romance, vale ressaltar que cada vez que essa pequena cidade imaginária se constrói e se destrói diante dos olhares de seus personagens e de seu leitor derradeiro, cada vez que esse romance escrito e circunscrito na esfera da leitura e da escritura se instaura, entendemos que estamos diante de um deslumbramento, co- mo leitores nos tornamos completamente solidários no maravilhoso e tra- remos na lembrança, por muito tempo, a imagem da primeira vez que nos foi mostrado o gelo pelo olhar de Aureliano Buendia. 
Em sintonia com as renovações estéticas e preocupações temáticas que percorreram o boom, está a novela Pedro Páramo (1955), do escritor mexicano Juan Rulfo. Ela apresenta em seu enredo um argumento que pode ser considerado simples, se comparado com a complexidade da trama que surge em suaforma fragmentada, delineada pela confluência de dife- rentes cronologias. Na obra, o personagem Juan Preciado conta como, a fim de cumprir a promessa feita a sua mãe moribunda, viaja a cidade de Coma- la para ajustar contas com seu pai, Pedro Páramo. Tal sequência, linear, no desenvolvimento da narrativa se estrutura pela fragmentação e cabe ao leitor o esforço de empreender múltiplas leituras a fim de identificar a origem das intrigas e estabelecer os diversos níveis temáticos que se desenvolvem no relato.

O tema que orienta a narrativa está ancorado no universo hispanoamericano e mexicano, mas antes de tudo, traduz uma construção própria ao gênero fantástico e revela, ainda, uma perspectiva universal se impõe na medida em que os conflitos descritos no enredo são regidos pela profusão de dramas humanos intensos, revelados pela ambição desmedida, pelos amores obsessivos, pela crueldade das vinganças. Em Pedro Páramo, a realidade de uma cultura é penetrada profundamente revelando, pelo viés das imagens insólitas um retrato da sociedade mexicana e dos perfis psicológico de seus habitantes.

Na novela,as referencias à realidade imediata e a representação da concretude cotidiana são retratadas com agudeza descritiva e possibilitam aos leitores o reconhecimento de ambientes absolutamente verossímeis, os leitores iniciam o relato adentrando um pequeno mundo familiar. Porém, essa é apenas a capa que reveste o retrato social elaborado por Juan Rulfo. Ao lado dessa concretude cotidiana, tudo gradativamente passa a sair de foco, tornando-se absurdo e abstrato. O surgimento do insólito permite uma experiência de leitura que percorre caminhos incertos, permeado pe- las dúvidas, pois, ainda que o verossímil continue articulando certos fatos da historia narrada, o leitor percebe que está diante de outro tipo de construção ficcional, aquele que o obriga a inserir-se em mundos imaginados, porém, não mais possíveis.

Este outro mundo que se constrói, imaginado e não possível, está povoado por pessoas mortas que parecem vivas ou por mortos que conduzem suas vidas e agem como se estivessem vivos. Na fragmentação surge a imagem do além-mundo, difuso, ambíguo e escorregadio, como a lembrança de um sonho. A estrutura fragmentada da narrativa revela-se como o 
caminho literário possível para contar a história da cidade de Comala, dos infortúnios que vividos por seus habitantes em tempos do cacique Pedro Páramo. A ausência de capítulos é um significante a mais que corrobora para que as diversas histórias se entrelacem no decorrer da novela. Os sal- tos cronológicos também são a base seminal para estruturar um enredo no qual as vozes que contam suas agruras não conseguem situar-se no mundo dos vivos ou no mundo dos mortos. Afinal, são mortos que contam a histó- ria ou seriam relatos fragmentados e dispersos de tempos diferentes? Se- gundo a estudiosa Jean Franco:

En esta novela, Rulfo abandona las convenciones de la disposición en capítulos y hace algo parecido a una orquestación. En el texto se intercalan fragmentos breves y a veces sin relación con lo que los rodea; trozos de diálogo o de monólogo, las voces del pueblo cuya identidad el lector sólo puede adivinar, forman lo sustancial del libro. La estructura es más poética que lógica, ya que los vínculos entre los diferentes pasajes son a menudo un tono, una palabra repetida o una asociación de recuerdos (FRANCO, 2002, p. 321).

Na obra são delineados dois blocos narrativos, de um lado a narração linear de Juan Preciado e de outro as historias relatadas pelos múltiplos narradores, que se constituem por fragmentos interpolados, explorando a inclusão de pensamentos e recordações de vários personagens. Um dos principais recursos estéticos que orienta o relato constitui-se pela elaboração de unidades narrativas autônomas, marcadas por pequenas diferenciações. É o caso dos fragmentos em itálico, que retratam toda lembrança idílica de Comala elaborada pela mãe de Juan Preciado. No caso do uso das aspas, observam-se as lembranças de Pedro Páramo comsua esposa Susana San Juan, que enlouquece. No entanto, outras narrativas que se entrecru- zam não são assinaladas, aparecem dispersas no texto e podem ser decifra- das no andamento da narrativa. Quando Juan Preciado chega àComala, inicia uma trajetória e nela se depara com um emaranhado discursivo sem identificação, assim, movido pela ilusão de encontrar suas origens, desco- bre pouco a pouco queComala é um povoado desabitado e cheio de fan-tasmas e acaba tomando consciência que está em meio a um mundo de mortos e que ele próprio está morto.

Quando Juan Preciado descreve seus motivos para ir à Comala, iniciase o processo de aprisionamento no mundo dos mortos, representado de maneira metafórica e sutil na imagem das mãos da mãe morta que retém 
as mãos do filho. Aqui se observa uma imagem precisa, mas que se redimensiona nos sentidos ambíguos próprios dos relatos fantásticos.

\begin{abstract}
Vine a Comala porque me dijeron que acá vivía mi padre, un tal Pedro Páramo. Mi madre me lo dijo. Y yo le prometí que vendría a verlo en cuanto ella muriera. Le apreté sus manos en señal de que lo haría, pues ella estaba por morirse y yo en un plan de prometerlo todo. "No dejes de ir a visitarlo - me recomendó. Se llama de este modo y de este otro. Estoy segura de que le dará gusto conocerte." Entonces no pude hacer otra cosa sino decirle que así lo haría, y de tanto decírselo se lo seguí diciendo aun después de que a mis manos les costó trabajo zafarse de sus manos muertas (RULFO, 2008, p. 65, grifo nosso).
\end{abstract}

Ainda que Juan Preciado seja de alguma forma o protagonista de uma jornada heroica, é Pedro Páramo o personagem central de todas as histórias que remontam a vida de Comala. As diferentes vozes que se insi- nuam e atormentam Juan Preciado não fazem mais do que recordar a histo- ria de Pedro Páramo. A história do 'cacique' sanguinário, do seu amor sem limites por Susana San Juan, de seu desespero após a sua morte e de sua vingança contra Comala.

O desconcerto provocado pelo insólito vai surgindo enquanto Juan Preciado perambula por Comala, ele mergulha em meio aos murmúrios dos tempos de Pedro Páramo e descobre que ele também é mais uma voz que murmura. O tempo passado se atualiza no presente de Juan Preciado e, dessa forma, a perspectiva temporal adquire uma profundidade de signifi-cados, pois alcança a significação imanente ao tempo do mito. No insólito descrito na obra, o presente e o passado se entrelaçam, surge um presente avassalador, que redimensiona a experiência de Juan Preciado. Narrando sua busca, vivendo um presente, ele encontra as narrativas de outras me- mórias, ele ingressa nos tempos do passado. O tempo do mito se instaura pela fragmentação da ordem temporal imposta pela profusão de narrativas, ele se impõe como o tempo determinante do além-mundo, torna-se profí- cuo, ainda que estarrecedor para o leitor que busca uma linearidade crono- lógica. A experiência da multiplicidade temporal, vivido por Juan Preciado em Comala, se traduz em uma experiência estética para os leitores. $\mathrm{O}$ in- gresso no tempo múltiplo dos fragmentos de vozes significa uma entrada no âmbito profundo da historicidade. Pelo viés do insólito revela-se a cruel- dade das esferas sociais latentes.

O desconcerto provocado pela narrativa seria a recriação do mundo da morte? Não. $O$ inquietante é que não se consegue situar as personagens no mundo dos vivos ou dos mortos. Segundo os estudos de Gonzáles Boxo" 
desde la época clásica la literatura ha recreado en mundo de la muerte sino que lo que inquieta es la dificultad para situar los personajes a un lado u otro de esa frontera (RULFO, 2008, p. 28). Todas as vivências de Juan Preciado em Comala estão impregnadas pela ambiguidade, que recria ao mesmo tempo a impressão de um mundo imaginativo, fantástico e do mundo aceito como real. Afinal, é possível perceber as muitas facetas que recobrem a realidade cotidiana? Quando nos deparamos com a multiplicidade de focos narrativos implícitos em Pedro Páramo, percebemos a sua relação crucial com o processo de composição da narrativa literária que consegue também tocar os limites da narrativa histórica. Na novela diferentes acon-

tecimentos são contados pela ótica de vários personagens, que sempre oscilam no movimento ambíguo de revelar e ocultar. De acordocom Jean Franco " las regiones de la ambigüedad, de planos de percepción irónicamente yuxtapuestos, son imposibles en la narrativa lineal, pero esto es lo que da su verdadero significado a la obra de Rulfo" (FRANCO, 2012, p. 323).

A leitura do insólito como imagem de uma visão critica da história alude a percepção da fragmentação dos relatos que envolvem a vida do cacique Pedro Páramo como uma forma de composição fragmentada e, talvez por isso, bastante verossímil da História mexicana. Uma história de fragmentos que se juntam pelo olhar de um leitor atento, capaz de entender as muitas construções narrativas que legitimam o nosso conhecimento do real. Nas entrelinhas da construção fragmentada de Pedro Páramo, aponta- se que as narrativas históricas se apoiam sempre motivações implícitas aos contextos e que é preciso ler a Historia juntamente com tais motivações e o arbítrio aos que estão condicionadas. O mundo no qual ingressa Juan Preciado é ambíguo justamente porque a realidade está povoada por narrativas múltiplas, marcadas por um caudal de percepções que evocam sempre possibilidades de verdades, de realidades. Por não saber o que define os sentidos de estar vivo ou morto, ou se vivos e mortos estão em posições discursivas equivalentes, o leitor é conduzido ao universo impreciso da leitura, destruída de sentidos óbvios, uma leitura que exige o desvendamento, uma leitura que é um exercício critico para pensarem-se as muitas formas de estar no mundo da realidade.

A Comala infernal é o lugar de Pedro Páramo, ela reproduz a imagem do 'cacique' latino-americano que vive submerso na violência e no exercício arbitrário do poder. Junto a essa imagem, aparece o panorama histórico da Revolução Mexicana, marcado pelo desalento, pelo desengano. Os aspectos históricos e culturais despontam em meio ao universo fantástico de um 
mundo de mortos que falam e contam suas historias. A imagem de uma Comala castigada remete aos sentidos da religião católica mesclada com as tradições das culturas orais. As superstições se juntam à doutrina oficial e quando o padre Renterianega a salvação aos habitantes de Comala, condena a todos a um castigo perpétuo. Da mesma maneira, Pedro Páramo amaldiçoa o povoado após a morte de Susana San Juan e nessas construções configuram-se a Comala metafórica, cenário dos embates religiosos e históricos que desenham o perfil multifacetado de México e da América Latina. 0 primeiro momento de leitura de Pedro Páramo nos parece a negação da História, pela ausência de linearidade; no entanto, ao consumar a leitura, percebe-se que justamente reside nesta ausência a sua capacidade de construção de verdades passadas e presentes. Proliferação de fatos e visões, ou seja, profusão de narrativas que nada mais são do que a imitação da realidade cotidiana. Cada indivíduo pode ordenar sua vida e sua percepção da realidade, da mesma forma que cada leitor ordena a história mexicana encoberta na vida do personagem Pedro Páramo.

Tanto a Comala infernal como a edênica revelam a Comala metafórica, que parte de uma realidade desconcertante, povoada por fantasmas, castigos e referencias a almas penadas para conjugar-se com a realidade extraliterária do "caudillismo" e do poder arbitrário de governos e instituições religiosas. O texto cria literariamente uma representação das vozes das pessoas "reais" que são enterradas no discurso histórico apresentado como oficial. A vida dos anônimos da história também se constitui por murmúrios e fragmentos, logo, em meio a uma descrição "insólita" surge um realismo subversivo. Os mortos de Comala remetem à vida na morte e também às muitas mortes em vida, perspectivas interessantes para pensar- se as grandes frustrações históricas individuais ou coletivas, como foi o caso da Revolução Mexicana. As esperançasquanto ao destino da Revolução pode ser metaforizado nas imagens do passado edênico de desejos e lem- branças, porém, ele ressurge no presente infernal da experiência da Histó- ria, nas frustrações, traições e decadências pós-revolução.

Na novela a realidade é percebida de forma escorregadia, Juan Preciado vive e sofre a história mexicana, que surge na forma de fragmentos históricos da Revolução, construídos a partir de uma realidade estilhaçada, marcados pela perspectiva subjetiva das personagens. Aqueles que lutaram na revolução mexicana - às vezes a favor de Villa, outras de Carranza sãoos sujeitos que vivenciaram o furacão da violência histórica e, no entanto, suas vozes tornam-se tão-somente registros numéricos, datas, ausên- 
cias. A visão histórica nem sempre permite o resgate das ambiguidades humanas, que são traduzidas por Rulfo na complexidade das posições revolucionarias antagônicas (ARRIGUCCI, 2010, p. 56). Esta forma de construção da História pela Literatura, tendo a fragmentação dos modelos de narrativa histórica como o principio que releva e obscurece as referenciais temporais, traduz-se como um caminho para demonstrar a pluralidade de vozes anônimas, silenciadas nas narrativas históricas apresentadas como oficiais.

A imagem da historia se conjuga a imagem insólita do além-túmulo na forma de um binômio dinâmico e inquietante. Os elementos fantásticos e imaginativos recriam esteticamente o universo de um mundo irreal, reiteradamente imaginado por quase todas as crenças religiosas. A concretude da História ressurge justamente nesse universo imaginativo, o insólito de Pedro Páramo torna-se o espaço privilegiado das promessas de entendi- mento da realidade, na forma do absurdo surge uma possibilidade de res- gatar a dinâmica quase sempre incompreensível do cotidiano dos sujeitos históricos - dispersos em seus desejos e sonhos.

Quando refletimos sobre obra do escritor mexicano Carlos Fuentes, é possível perceber uma insistente discussão a respeito dos mecanismos de sobrevivência e até mesmo de resistência cultural presentes no continente latino-americano. Sua obra ficcional e ensaística está marcada pelos temas que percorrem a multiplicidade cultural latino-americana sem, no entanto, cravar-se em uma visão totalizadora. $O$ escritor mexicano procurou perceber e destacar as muitas individualidades que formam a voz pluricultural da América Latina, cada sujeito, representado em seus romances e contos, compõe uma amplitude cultural marcada pelos eixos da diacronia histórica, logo, torna-se ícone representativo da profusão de temporalidades que perpassa o cotidiano do sujeito latino-americano. Assim, para compreender os tempos do passado, do presente e do futuro, que convivem em uma relação simbiótica, Fuentes criou um imaginário literário que parte de um pressuposto crítico tantas vezes destacados em suas entrevistas e ensaios. Segundo Fuentes "el pasado no ha concluido; el pasado tiene que ser reinventado a cada momento para que no se fosilice entre las manos" (FUENTES, 1990, p. 23). Ou, ainda, emseulivro de ensaiosTiempo mexicano, "la coexistencia de todos los niveles históricos en México es solo el signo externo de una decisión subconsciente de esta tierra y esa gente: todo tiempo debe ser mantenido. ¿Por qué? Porque ningún tiempo mexicano se ha cumplido aún" (FUENTES, 1971, p. 10). 
Os pressupostos críticos de Fuentes, que se referem à historicidade, assim como os aspectos, que remetem a formação cultural dos povos latino-americanos, se traduzem em sua obra Aura, de1962 A novela, ainda que esteja efetivamente aberta a muitas leituras, alcançou significativa repercussão por sua construção ancorada nos preceitos da literatura fantástica. No presente estudo, procura-se observar como um importante registro histórico e cultural permanece imanente às imagens próprias da literatura fantástica, demonstrando, assim, um comprometimento realista com os aspectos fantásticos, desvinculados, aparentemente das com as formulações críticas culturais e históricas.

$\mathrm{O}$ argumento da novela se sustenta pelas imagens de impacto fantástico, pois, a trama se desenvolve a partir da suspeita de que as duas personagens principais do relato, a jovem Aura e a anciã Consuelo, são na verdade uma só pessoa, ambas configuram existências duplas. $O$ insólito não para nesse conflito, ele se amplia gradativamente e, ao fim, desvenda-se para os leitores o mistério de outras existências duplicadas, pertencentes aos personagens Felipe Montero e General Llorente.

A trama que compreende esse relato de mistérios e enganos é narrada na 2a . pessoa, ou seja, é a partir de um foco narrativo centrado em um "tú" que são descritos os acontecimentos marcados pelo tom premonitório e dúbio. O recurso formal que parte da utilização do "tú" como condutor da narrativa também permite que os leitores sintam-se incluídos no andamento da historia narrada. Afinal, ao dirigir-se constantemente a um narratario não nomeado, os leitores são evocados, a todo o momento, a seguir os passos de Felipe Montero, protagonista do relato. Essa arquitetura da trama, ainda que inovadora, estabelece um forte vínculo com a forma clássica do narrador-testemunha, muito presente na narrativa fantástica predominante no século XIX e largamente estudada por T. Todorov em sua obra Introdução à literatura fantástica (1980). Segundo Todorov, a presença do narrador em $1^{\text {a }}$ pessoa no relato fantástico reforça os sentidos da verossimilhança, uma vez que estabelece um vínculo estreito entre o narrador personagem e o leitor implícito, manifestando, dessa forma, uma intensificação da tensão implícita ao fato narrado, levando o leitor a pactuar com a 'hesitação' do narrador.

É possível entender que essa perspectiva estudada por Todorov também se ajusta ao narrador na segunda pessoa, pois, em ambos recursos de elaboração do foco narrativo, evoca-se a autoridade sobre a ação narrada e o consequente convencimento do leitor implícito. Seja pelo olhar do narra- 
dor-testemunha, seja pelo olhar de um 'tú' imperativo que domina os passos dos personagens, os leitores são conduzidos pelo enredo por uma visão exterior etotalizadora, parcial e, logo, aprisionadora.

Em Aura toda a atmosfera que faz parte da composição do ambiente próprio ao fantástico surge de maneira inequívoca. Toda estrutura narrativa da novela é elabora de forma cuidadosa e corrobora para a atmosfera própria ao gênero fantástico. Ainda que estejamos diante de uma obra escrita no século $X X$, que utiliza formulações estéticas ousadas e que rompe com as estrutura narrativa mais tradicional, é possível identificar algumas correspondências com os preceitos narrativos do fantástico que se tornou referencia nos textos desenvolvidos no século XIX. A descrição do casarão onde vivem Aura-Consuelo estabelece uma relação estreita com as muitas casas que pertencem a tradição dos contos fantásticos ou de terror. 0 ambiente é desprovido de iluminação,na entrada existem plantas raras de poder alucinógeno, a decoração do quarto de Consuelo aproxima-se um barroquismo opressor em seus excessos, dificultando uma visão clara do espaço. A casa se esconde pela descrição do fantástico, porém, ela se revela nitidamente pela elaboração estética apreendida pelo leitor.

Outro aspecto, que corrobora para construção do fantástico é o acumulo de ambiguidades e imprecisões que perpassam o relato. A casa onde reside Aura e a Sra. Consuelo está situada no centro velho da cidade do México e surge numerada duas vezes, revelando um primeiro sinal de incerteza, de confusão e irrealidade. Cabe destacar que esse detalhe 'realista' remete a sobreposição que ocorrerá entre os personagens Aura e Consuelo e, posteriormente, entre Felipe Montero e o General Llorente. Essa sobreposição é, acima de tudo, uma sobreposição de tempos. A casa pertence a dois tempos, possui duas numerações assim como aqueles que habitam, pertencem a duas ordens temporais, distintas e simultâneas.

Todos os diálogos entre Felipe e Aura-Consuelo estão marcados pelo duplo sentido e colaboram para criar a tensão do fantástico. Logo, decifrar o diálogo é a condição para revelar o verdadeiro "eu" de Aura-Consuelo e Felipe-Llorente. Esse momento do relato explicita a sobreposição de tem- pos e identidades e assim surgem as vozes históricas do México antigo com suas referencias a mitologia asteca e a usurpação de identidades pelos espanhóis. E, também, o México do século XIX, representado na alusão ao império de Maximiliano de Hasburgo, outro momento histórico de luta pela identidade mexicana. O México contemporâneo se revela nas imagens construídas pelos mecanismos da narrativa fantástica, pois o esforço por 
entender as identidades plurais que formam a cultura mexicana - surgidas a partir da conquista e da colonização espanhola (referência ao projeto de narrativa histórica que deseja elaborar Felipe), está metaforizada no percurso de Felipe Montero no mundo de Aura, Consuelo e General Llorente. A narrativa de Aura constrói-se por meio de uma circularidade expressa no deslocamento de Felipe Montero, ele viaja pela História até a origem (para conhecer sua verdadeira identidade). Do café até a casa de Consuelo, localizada na parte mais histórica da cidade, significa iniciar o "circulo" de uma viagem sem volta, trata-se de uma viagem de regresso ao que ele foi.

Os estudos teóricos de RosalbaCampra e Jaime Alazraki sobre a narrativa fantástica apontam renovadas possiblidades de interpretação do relato fantástico contemporâneo e podem ser utilizados para orientar uma reflexão sobre os sentidos do insólito quando conjugado aos tempos sobrepostos e às identidades plurais. O fantástico permite a perspectiva de um olhar crítico a respeito da cultura mexicana, paradoxalmente realista, elaborado pelo viés da construção de uma realidade desconcertante, absurda e transgressora. O fantástico revela, assim,a realidade em sua ambivalência, como destaca RosalbaCampra (2008, p. 191):

La función de lo fantástico, tanto hoy como en 1700, aunque a través de mecanismos bien diferentes - y que indican los cambios de una sociedad, de sus valores, en todos los órdenes - sigue siendo la de iluminar por un mo- mento los abismos de lo incognoscible que existen fuera y dentro del hom- bre, de crear por lo tanto una incertidumbre en toda la realidad.

O autor mexicano, em sua obra, resgata a presença das tradições culturais e da memória histórica por meio das imagens próprias ao fantástico. Posto que a estrutura dos relatos fantásticos permite a existência de um limitar que não separa diferentes tempos ou instancias de realidade, podese estabelecer um paralelo entre a uma reflexão multitemporal, própria de Carlos Fuentes, e a estruturação deste relato fantásticos, que funcionaria como ponto de coesão de diferenças ordens temporais hispano- americanas. Ao trazer para suas obras os diferentes fragmentos culturais que compõem o acervo mexicano, Fuentes não sobrepõe nenhuma das partes deste acervo, ao contrário, cada parte está lado a lado, buscando revelar que não há supremacia cultural, há apenas diferença, essa concep- ção crítica das identidades encontra respaldo na estética ambivalente do fantástico.

Nas três obras destacadas nesse estudo, observa-se que as imagens do insólito conjugamaspectos do presente e do passado, aglutinando senti- dos históricos e criando uma estrutura possível para unir a diversidade 
temporal hispano-americana. A narrativa fantástica que se articula em Fuentes, Rulfo ou García Márquez estabelece uma diretriz temática que discute a convivência dos diferentes tempos históricos e das diferentes culturas que persistem como substrato vivo do mundo hispânico. Nestas obras, os sentidos mais profundos do fantástico adquirem novos matizes quando confrontados com a realidade histórica e mítica, as imagens do insólito trazem o mundo para dentro da literatura e conseguem penetrar seus aspectos mais intangíveis.

\section{REFERÊNCIAS}

ARRIGUCCI, D. O guardador de segredos. São Paulo: Cia. das Letras, 2010.

CAMPRA, R. Territorios de la ficción. Lo fantástico. Espanha: Renascimento, 2008.

CHIAMPI, I. O realismo maravilhoso. São Paulo: Perspectiva,1980

FUENTES, C. Tiempo mexicano. 3. ed. México: Joaquín Mortiz, 1971.

FUENTES, C. Aura. Ediciones Era, 1981.

FURTADO, F. A construção do fantástico na narrativa. Lisboa: Horizonte, 1980.

FRANCO, J. Historia de la literatura hispanoamericana. Barcelona: Ariel, 2002.

GARCÍA MÁRQUEZ, G. Cem anos de solidão. Rio de Janeiro: Record, s/d

HUSTON, N. A espécie fabuladora. São Paulo: L\&PM, 2010.

KAFKA, F. A metamorfose. São Paulo: Nova Época Editorial, s/d

RODRÍGUEZ MONEGAL, E. La nueva novela latinoamericana. In Narradores de esta América. Montevideo: Alfa, 1972, p. 11-36.

RULFO, J. Pedro Páramo. Ed. José Carlos RodríguezBoxo. Madrid: Cátedra, 2008.

SARTRE, J. P. Situações I: críticas literárias. São Paulo: Cosac Naify, 2005.

TODOTOV, T. Introdução à literatura fantástica. São Paulo: Perspectiva, 1975. 